\title{
Preservative Evaluation of Caprylic Acid Derivatives in Aluminium Hydroxide Gel - USP
}

\author{
Jasmine ChaudhaRY ${ }^{1}$, Archana K. RAJPAL ${ }^{1}$, Vikramjeet JUdGE ${ }^{1}$, \\ Rakesh NARANG ${ }^{1}$, Balasubramanian NARASIMHAN * 2 \\ ${ }^{1}$ Department of Pharmaceutical Sciences, Guru Jambheshwar \\ University of Science and Technology, Hisar-125001, India \\ ${ }^{2}$ Faculty of Pharmaceutical Sciences, \\ Maharshi Dayanand University, Rohtak-124001, India
}

\begin{abstract}
The potential derivatives of caprylic acid were subjected to preservative efficacy testing in Aluminium Hydroxide Gel - USP using Staphylococcus aureus MTCC 2901, Bacillus subtilis MTCC 2063, and Escherichia coli MTCC 1652 as representative challenging microorganisms for antimicrobial effectiveness testing as per USP 2004. The caprylic acid derivative, capryl hydrazide exhibited better preservative efficacy than caprylic acid as well as the standard preservatives, methyl paraben and propyl paraben.
\end{abstract}

\section{Keywords}

Caprylic acid $\bullet$ Capryl hydrazide $\bullet p$-Chlorocaprylanilide $\bullet$ Preservative efficacy

\section{Introduction}

High degree of water availability in pharmaceutical products may give rise to their contamination by microorganisms which may cause spoilage of the product along with loss of therapeutic properties and, if they are pathogenic, serious infections can arise [1,2]. Therefore, preservatives are being added to the preparations to prolong their shelf life by preventing the microbial attack [3]. The 
antibacterial and antifungal properties of fatty acids have been studied extensively and the development and use of safe antimicrobial preservatives in pharmaceutical preparations continue to be of great interest to the pharmaceutical industry $[2,4,5]$. In continuation of our ongoing research work on development of preservatives, the present study was designed to evaluate the preservative effectiveness of caprylic acid derivatives against three representative bacterial strains and comparing it with the standard preservatives (methyl and propyl paraben) [2, 5].

\section{Experimental}

\section{Materials}

Nutrient agar - I.P. and nutrient broth - I.P. [6] and Aluminium hydroxide gel were obtained from Himedia, Mumbai. Mannitol, methyl- and propylparaben were obtained from $\mathrm{CDH}$, Mumbai.

\section{Methods}

Aluminium Hydroxide Gel - USP was used as the pharmaceutical product for evaluation of preservative efficacy testing.

\section{Preparation of Aluminum Hydroxide Gel-USP [7]}

\section{Formula}

Aluminium hydroxide gel $-36 \mathrm{~g}$; Mannitol $-7 \mathrm{~g}$; Methylparaben $-0.2 \mathrm{~g}$; Propylparaben - 0.02 g; Saccharin - 0.05 g; Peppermint oil - $0.005 \mathrm{~mL}$; Alcohol - 1 $\mathrm{mL}$; Purified water q.s. $-100 \mathrm{~mL}$.

The weighed quantity of Aluminum hydroxide gel and mannitol were triturated with $50 \mathrm{~mL}$ of water in a mortar. Methylparaben, propylparaben, saccharin and peppermint oil were dissolved in alcohol and added to above mixture and triturated well. The volume was made up to $100 \mathrm{~mL}$ with purified water.

For preservative efficacy testing, the Aluminium hydroxide gel was prepared using the preservatives mentioned in Table 1 by replacing methylparaben and propylparaben from the above formula. The equimolar amount of selected 
preservatives (Table 1) were calculated with reference to the amount of methyl paraben $(0.0013 \mathrm{~mol})$ and added into the pharmaceutical products.

Tab. 1. Amount of selected preservatives added in the pharmaceutical product

\begin{tabular}{lll}
\hline Code & Preservative & Amount (g) \\
\hline $\mathrm{C}_{1}$ & Caprylic acid & 0.18 \\
$\mathrm{C}_{2}$ & Capryl hydrazide & 0.20 \\
$\mathrm{C}_{3}$ & $p$-Chlorocaprylanilide & 0.32 \\
\hline
\end{tabular}

\section{Preservative efficacy testing in pharmaceutical products [8]}

Aluminum hydroxide gel prepared with different preservatives was sterilized in autoclave at $120^{\circ} \mathrm{C}$ for 15 minutes. The products were then inoculated separately with bacterial suspensions containing $2 \times 10^{6} \mathrm{CFU} / \mathrm{mL}$ of Staphylococcus aureus MTCC 2901, Bacillus subtilis MTCC 2063, and Escherichia coli MTCC 1652 (24 h fresh culture in nutrient broth - I.P.). The CFU/mL of the product was determined at an interval of $0,7,14,21$, and 28 days by transferring the $1 \mathrm{ml}$ of the product to nutrient agar - I.P. which were then incubated at $37^{\circ} \mathrm{C}$ for $24 \mathrm{~h}$. The log values of number of colonies of microorganisms per ml (Table 2 - Table 4) of Aluminium hydroxide gel were calculated and compared as per the guidelines of USP 2004. All the experiments were performed in triplicate and the results presented in Table 2, 3 and 4 are mean \pm SD of log values of CFU/mL.

\section{Results and Discussion}

\section{For S. aureus:}

The results observed for the preservative efficacy testing against $S$. aureus are presented in Table 2 . In case of caprylic acid $\left(C_{1}\right)$ there was no increment in CFU/mL on $14^{\text {th }}$ day $(0.000 \pm 0.00)$ as well as on the $28^{\text {th }}$ day $(0.301 \pm 0.24)$ than the previous value measured. Hence it passes the preservative efficacy test. In case of capryl hydrazide $\left(C_{2}\right)$, there was no increment in log values of CFU/mL on $14^{\text {th }}$ day $(0.000 \pm 0.00)$ and only 0.3 log unit increment on $28^{\text {th }}$ day $(0.301 \pm 0.00)$. 
So, it also passes the preservative effectiveness test. The log CFU/mL values remain unchanged on $14^{\text {th }}$ day $(0.301 \pm 0.00)$ and there was only a small increment in log CFU/mL on $28^{\text {th }}$ day $(0.698 \pm 0.24)$ in case of $p$-chlorocaprylanilide $\left(C_{3}\right)$ which is in accordance with the prescribed pharmacopoeial guidelines, hence it also passes the preservative efficacy test. The standard also met the USP requirements.

Tab. 2. Bacterial count (CFU/ $\mathrm{mL}$ ) of $S$. aureus in Aluminium Hydroxide Gel USP supplemented with preservatives

\begin{tabular}{llllll}
\hline Compound & \multicolumn{4}{c}{ Log $(\mathrm{CFU} / \mathrm{mL}) \pm$ SD (Time in days) } \\
\cline { 2 - 6 } & $\mathbf{0}$ & $\mathbf{7}$ & $\mathbf{1 4}$ & $\mathbf{2 1}$ & $\mathbf{2 8}$ \\
\hline Caprylic acid $\left(\mathrm{C}_{1}\right)$ & $0.000 \pm$ & $0.000 \pm$ & $0.000 \pm$ & $0.301 \pm$ & $0.301 \pm$ \\
& 0.24 & 0.24 & 0.00 & 0.24 & 0.24 \\
Capryl hydrazide $\left(\mathrm{C}_{2}\right)$ & $0.000 \pm$ & $0.000 \pm$ & $0.000 \pm$ & $0.000 \pm$ & $0.301 \pm$ \\
& 0.00 & 0.00 & 0.00 & 0.00 & 0.00 \\
p-Chlorocaprylanilide $\left(\mathrm{C}_{3}\right)$ & $0.000 \pm$ & $0.301 \pm$ & $0.301 \pm$ & $0.301 \pm$ & $0.698 \pm$ \\
& 0.24 & 0.24 & 0.00 & 0.00 & 0.24 \\
Methyl- and Propyl paraben & $0.602 \pm$ & $0.301 \pm$ & $0.000 \pm$ & $0.301 \pm$ & $0.477 \pm$ \\
& 0.05 & 0.08 & 0.00 & 0.08 & 0.09 \\
Control & $0.903 \pm$ & $0.477 \pm$ & $0.602 \pm$ & $0.778 \pm$ & $0.778 \pm$ \\
& 0.02 & 0.08 & 0.05 & 0.03 & 0.03 \\
\hline
\end{tabular}

For B. Subtilis:

As per the results shown in Table 3 caprylic acid $\left(C_{1}\right)$ met the USP limits on $14^{\text {th }}$ day $(1.230 \pm 0.24)$ as well as on $28^{\text {th }}$ day $(1.301 \pm 0.00)$ as the increment in log $\mathrm{CFU} / \mathrm{mL}$ value was within the prescribed $0.5 \mathrm{log}$ units. The capryl hydrazide $\left(\mathrm{C}_{2}\right)$ had shown complete inhibition of bacterium on $14^{\text {th }}$ day $(0.000 \pm 0.00)$ and there was no increment in log $\mathrm{CFU} / \mathrm{mL}$ values on $28^{\text {th }}$ day $(0.301 \pm 0.24)$ as well, which confirms its preservative efficacy potential. The derivative $p$-chlorocaprylanilide $\left(\mathrm{C}_{3}\right)$ fails to meet the pharmacopoeial limits on $14^{\text {th }}$ day (log CFU/mL increases from 0.698 to 1.397 ) which is more than 0.5 log unit increment but it diminishes the bacterial growth on $28^{\text {th }}$ day (1.792 to 2.000)to a level which is within the pharmacopoeial limits. The standard methyl- and propylparaben also fails to meet the pharmacopoeial requirements on $28^{\text {th }}$ day. In the present study, even though the $B$. subtilis is not specified as a test organism for the preservative efficacy testing 
in USP, it has been selected as a test organism being it is mentioned in the Indian Pharmacopoeia as a possible aerobic microbial contaminant of pharmaceutical substances [6]. Further, the Bacillus species synthesize a necrotic enterotoxin, possibly in conjunction with the primary haemolysin which may be responsible for nongastrointestinal bacillus infection [9].

Tab. 3. Bacterial count (CFU/ $\mathrm{mL}$ ) of $B$. subtilis in Aluminium Hydroxide Gel USP supplemented with preservatives

\begin{tabular}{|c|c|c|c|c|c|}
\hline \multirow[t]{2}{*}{ Compound } & \multicolumn{5}{|c|}{$\log (C F U / m L) \pm S D$ (Time in days) } \\
\hline & 0 & 7 & 14 & 21 & 28 \\
\hline \multirow[t]{2}{*}{ Caprylic acid $\left(\mathrm{C}_{1}\right)$} & $0.000 \pm$ & $0.845 \pm$ & $1.230 \pm$ & $1.176 \pm$ & $1.301 \pm$ \\
\hline & 0.24 & 0.00 & 0.24 & 0.00 & 0.00 \\
\hline \multirow[t]{2}{*}{ Capryl hydrazide $\left(\mathrm{C}_{2}\right)$} & $0.301 \pm$ & $0.000 \pm$ & $0.000 \pm$ & $0.301 \pm$ & $0.301 \pm$ \\
\hline & 0.24 & 0.00 & 0.00 & 0.00 & 0.24 \\
\hline \multirow[t]{2}{*}{$p$-Chlorocaprylanilide $\left(\mathrm{C}_{3}\right)$} & $0.000 \pm$ & $0.698 \pm$ & $1.397 \pm$ & $1.792 \pm$ & $2.000 \pm$ \\
\hline & 0.24 & 0.00 & 0.18 & 0.06 & 0.06 \\
\hline \multirow[t]{2}{*}{ Methyl- and Propyl paraben } & $0.602 \pm$ & $0.477 \pm$ & $0.000 \pm$ & $0.000 \pm$ & $0.778 \pm$ \\
\hline & 0.05 & 0.09 & 0.00 & 0.00 & 0.03 \\
\hline \multirow[t]{2}{*}{ Control } & $0.699 \pm$ & $0.602 \pm$ & $1.110 \pm$ & $0.301 \pm$ & $0.845 \pm$ \\
\hline & 0.04 & 0.05 & 0.02 & 0.08 & 0.03 \\
\hline
\end{tabular}

For E. coli:

In case of preservative effectiveness testing against $E$. coli, the parent compound caprylic acid $\left(C_{1}\right)$ fails to meet the pharmacopoeial limits on $28^{\text {th }}$ day $(1.000 \pm 0.24)$, hence it fails the preservative effectiveness test. The derivative capryl hydrazide $\left(\mathrm{C}_{2}\right)$ passes the preservative efficacy test on $14^{\text {th }}$ day $(0.000 \pm$ $0.00)$ as well as on $28^{\text {th }}$ day $(0.477 \pm 0.09)$. The another derivative $p$ chlorocaprylanilide $\left(C_{3}\right)$ meets the pharmacopoeial limits on $14^{\text {th }}$ day $(0.301 \pm 0.24)$ and $28^{\text {th }}$ day $(0.698 \pm 0.00)$ as the increment in log CFU/mL values was within the prescribed 0.5 log unit. The standard fails to meet the USP guidelines.

The derivative capryl hydrazide $\left(C_{2}\right)$ was active against all the tested strains of microorganisms and it meets the requirements of USP NF 2004. The derivative $p-$ chlorocaprylanilide $\left(\mathrm{C}_{3}\right)$ was also active against the tested microorganisms except 
in case of $B$. subtilis against which it fails to meet the USP guidelines on $14^{\text {th }}$ day but was found to be active in later period of study.

Tab. 4. Bacterial count (CFU/ mL) of $E$. coli in Aluminium Hydroxide Gel USP supplemented with preservatives

\begin{tabular}{|c|c|c|c|c|c|}
\hline \multirow[t]{2}{*}{ Compound } & \multicolumn{5}{|c|}{$\log (C F U / m L) \pm S D($ Time in days) } \\
\hline & 0 & 7 & 14 & 21 & 28 \\
\hline \multirow[t]{2}{*}{ Caprylic acid $\left(\mathrm{C}_{1}\right)$} & $0.602 \pm$ & $0.301 \pm$ & $0.000 \pm$ & $0.000 \pm$ & $1.000 \pm$ \\
\hline & 0.00 & 0.24 & 0.00 & 0.24 & 0.24 \\
\hline \multirow[t]{2}{*}{ Capryl hydrazide $\left(\mathrm{C}_{2}\right)$} & $0.301 \pm$ & $0.000 \pm$ & $0.000 \pm$ & $0.000 \pm$ & $0.477 \pm$ \\
\hline & 0.24 & 0.00 & 0.00 & 0.00 & 0.09 \\
\hline \multirow[t]{2}{*}{$p$-Chlorocaprylanilide $\left(\mathrm{C}_{3}\right)$} & $0.000 \pm$ & $0.000 \pm$ & $0.301 \pm$ & $0.602 \pm$ & $0.698 \pm$ \\
\hline & 0.00 & 0.00 & 0.24 & 0.00 & 0.00 \\
\hline \multirow[t]{2}{*}{ Methyl- and Propyl paraben } & $0.778 \pm$ & $0.000 \pm$ & $0.602 \pm$ & $0.301 \pm$ & $0.699 \pm$ \\
\hline & 0.03 & 0.00 & 0.05 & 0.08 & 0.04 \\
\hline \multirow[t]{2}{*}{ Control } & $0.845 \pm$ & $0.602 \pm$ & $0.778 \pm$ & $0.954 \pm$ & $1.041 \pm$ \\
\hline & 0.03 & 0.05 & 0.03 & 0.0 & 0.0 \\
\hline
\end{tabular}

\section{Conclusion}

The selected derivatives have exhibited promising preservative potential. The test compound capryl hydrazide $\left(\mathrm{C}_{3}\right)$ was found to be active against all the tested microbial strains under the prescribed test conditions as per USP 2004 i.e. for antacid made with an aqueous base, preservative effectiveness are met if there is no increase from initial calculated count at $14^{\text {th }}$ and $28^{\text {th }}$ day in case of all the tested bacterial strains. The USP 2004 defines no increase as not more than $0.5 \log _{10}$ units higher than previous value measured. The above fact was supported by the $\log \mathrm{CFU} / \mathrm{mL}$ values of capryl hydrazide $\left(\mathrm{C}_{3}\right)$ for $0-28$ days viz. $0.000-0.301$ (S. aureus), $0.301-0.301$ (B. subtilis), $0.301-0.477$ (E. coli) which were in accordance with the prescribed USP criteria. The results of preservative efficacy testing indicated that capryl hydrazide $\left(\mathrm{C}_{3}\right)$ has the potential to be chosen as a pharmaceutical preservative. $p$-Chlorocaprylanilide also had shown good results [0.000 - 0.698 (S. aureus) and $0.000-0.698$ (E. coli)] except against B. subtilis $(0.000-2.000)$. 


\section{References}

[1] Zani F, Minutello A, Maggi L, Santi P, Mazza P.

Evaluation of preservative effectiveness in pharmaceutical products: the use of a wild strain of Pseudomonas cepacia

J Appl Microbiol. 1997; 83: 322-326.

[doi:10.1046/j.1365-2672.1997.00231.x]

[2] Judge V, Narasimhan B, Narang R, Ohlan R, Ohlan S.

Preservative Evaluation of Novel 2,4-Hexadienoic Acid Derivatives in

Aluminium Hydroxide Gel - USP.

Sci Pharm. 2008; 76: 269-277.

[doi:10.3797/scipharm.0803-14]

[3] Akpan UG, Mohammed AD, Aminu I.

Effect of preservative on the Shelf Life of Yoghurt Produced from Soya Beans Milk.

Leonardo Electron J Pract Technol. 2007; 11: 131-142.

[4] Beuchat LR.

Comparison of Anti- Vibrio Activities of Potassium Sorbate, Sodium Benzoate, and Glycerol and Sucrose Esters of Fatty Acids.

Appl Environ Microb. 1980; 39: 1178-1182.

[5] Narasimhan B, Singh N, Panghal A, Dhake A.

Efficiency of Anacardic Acid as Preservative in Tomato Products.

J Food Process Pres. 2008; 32: 600-609.

[doi:10.1111/j.1745-4549.2008.00201.x]

[6] Pharmacopoeia of India.

Ministry of Health Department, Govt. of India, New Delhi, 1996; Vol. II, A-88 and $\mathrm{A}-116$.

[7] Lachman L, Lieberman HA, Kanig JL.

In: The Theory and Practice of Industrial Pharmacy.

$3^{\text {rd }}$ Ed., Vargheese Publishing House, Bombay, 1987: 498-499.

[8] The United States Pharmacopoeia.

United States Pharmacopoeial Convention, Inc, Rockville, 2004: 2148-2150.

[9] Turnbull PC, Kramer JM.

Non-gastrointestinal Bacillus cereus infections: an analysis of exotoxin

production by strains isolated over two years period.

J Clin Pathol. 1983; 36: 1091-1096.

[doi:10.1136/jcp.36.10.1091]

Received July $30^{\text {th }}, 2008$

Accepted (after revision) September $1^{\text {st }}, 2008$

Available online at www.scipharm. at September $2^{\text {nd }}, 2008$ 